\title{
Pengujian Model Bumi Referensi dan Solusi CMT gempa C081097A dan B122500C melalui Perbandingan Seismogram 3-Komponen di Stasiun-stasiun Observasi di Australia
}

\author{
Bagus Jaya Santosa* \\ Jurusan Fisika, FMIPA-Institut Teknologi Sepuluh Nopember (ITS) \\ Kampus ITS Sukolilo, Surabaya 60111
}

\begin{abstract}
Intisari
Dalam penelitian ini seismogram observasi dengan sintetiknya dari dua gempa yaitu C081097A, Australia Barat dan gempa B122500C, Australia Selatan dibandingkan dalam domain waktu dan komponen ruang 3 dimensi. Stasiun pengamat terletak di WRAB, NWAO, CTAO dan TAU, Australia. Seismogram sintetik dihitung dari sebuah model bumi standard PREMAN dan IASPEI91 dan solusi CMT dari gempa-gempa tersebut. Seismogram dikenakan filter lolos rendah $30 \mathrm{mHz}$. Perbandingan seismogram dijumpai diskrepansi yang sangat kuat dan tidak sistimatis pada waktu tempuh dan waveform milik fase-fase gelombang utama. Terlihat gelombang Love ternyata sangat peka terhadap perubahan ketebalan kulit bumi, namun gelombang Rayleigh terpengaruh sedikit. Ini menjadi petunjuk, bagaimana menginterpretasikan ketebalan kulit bumi. Diskrepansi yang kuat juga diamati pada perbandingan seismogram untuk gelombang-gelombang body. Ini menunjukkan adanya kesalahan / kekuranglengkapan pada model struktur bumi elastik yang sering diacu oleh seismolog lainnya.
\end{abstract}

KATA KUNCI: model bumi, solusi CMT, analisa seismogram

\section{PENDAHULUAN}

Sebuah gempa yang besar menghasilkan gerakan tanah yang dapat dicatat di hampir seluruh permukaan bumi (jika kekuatan gempa di atas 5,6 skala Richter). Melalui seismometer yang sensitif di stasiun penerima, gerakan tanah akibat gempa tersebut direkam dan disajikan kembali sebagai seismogram. Seismogram tersusun atas fase-fase gelombang yang kompleks, berasal dari refleksi/refraksi yang terjadi di dalam bumi, akibat adanya perbedaan parameter elastik pada medium perlapisan bumi, sepanjang perjalanan gelombang dari sumber gempa hingga penerima.

Dari seimogram kita dapat mencatat waktu tiba dan amplitudo milik beberapa fase gelombang utama dan hubungan dispersi kecepatan - perioda pada gelombang permukaan. Melalui pengamatan atas waktu tiba gelombang-gelombang utama pada serangkaian seismometer yang melingkupi daerah sumber gempa, dapat ditentukan kedudukan episenter gempa. Selain itu polaritas gelombang pertama $\mathrm{P}$ juga dicatat, guna menentukan arah sesar gempa. Solusi CMT atas gempa dikerjakan pada seismogram dengan perioda pendek. Seismogram sintetik, dihitung dengan metoda fungsi Green's, yang dibentuk dari sebuah model bumi. Seismogram sintetik dihitung untuk tiap komponen arah tensor dalam tiga komponen Kartesian, untuk membentuk matriks Kernel. Seismogram sintetik kemudian dibandingkan dengan seismogram riil, pada ham-

*E-MAIL: bjs@physics.its.ac.id pir semua fase-fase gelombang dalam domain waktu, perbedaan deret amplitudo antara kedua seismogram berlaku sebagai vektor variabel yang diketahui. Dilakukan inversi untuk mendapatkan solusi CMT dari gempa tersebut $[1,2]$.

Sebuah pengandaian model bumi, khususnya model 1-D, diperlukan untuk menghitung simulasi atas besaran fisis yang terukur, yaitu waktu tempuh gelombang, polaritas gelombang dan amplitudo. Model bumi juga diperlukan dalam penentuan solusi CMT sumber gempa. Data seismogram juga dapat digunakan untuk menurunkan sebuah model bumi. Ada 3 metode yang digunakan untuk menurunkan model bumi, yaitu analisa atas waktu-waktu tiba fase-fase gelombang ruang (body wave), analisa dispersi pada gelombang permukaan dan perbandingan seismogram dalam kawasan waktu. Dua metoda pertama hanya mengevaluasi sedikit informasi tertentu dalam sebuah deret waktu seismogram, sedangkan metoda ketiga adalah yang terbaik, karena akan diperbandingkan keseluruhan informasi yang terkandung dalam seismogram [3].

Model bumi IASPEI91 [4] dan PREMAN [5] diturunkan dari kompilasi atas jutaan waktu tempuh gelombang dari ribuan pasangan sumber gempa-stasiun pencatat. Parameter fisika yang dapat diturunkan dari kurva waktu tempuh hanyalah kecepatan penjalaran gelombang $\alpha$ dan $\beta$. Untuk melengkapi parameter elastik yang lain digunakan analisa dispersi pada gelombang permukaan. Dari kedua metoda ini dihasilkan model bumi elastik dengan parameter lengkap, meliputi rapat massa, kecepatan rambat $\alpha_{v}, \alpha_{h}$ dan $\beta_{v}, \beta_{h}$, kualitas redaman $\mu$ dan $\kappa$ dan anisotropi.

Jika sebuah gempa bumi terjadi, Lembaga Seismologi di 


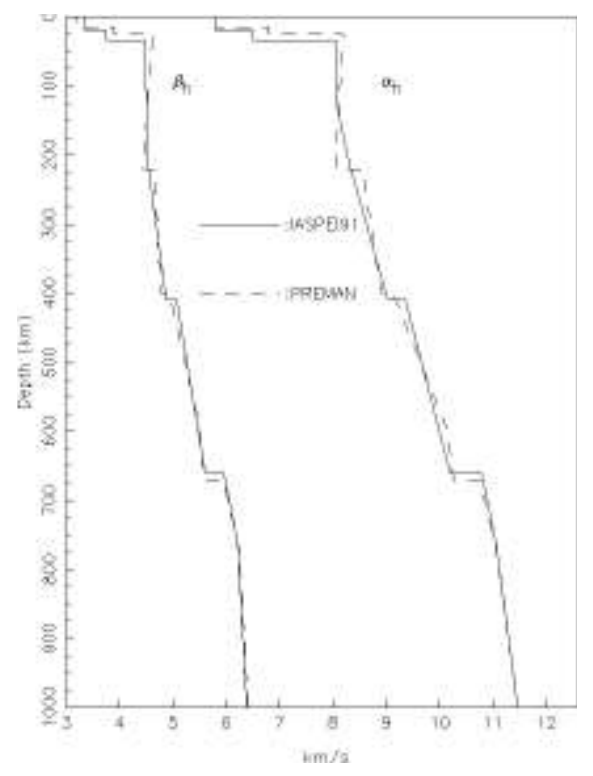

Gambar 1: Penampang model bumi dari kedua model bumi standar, IASPEI91 dan PREMAN hingga kedalaman $1000 \mathrm{~km}$.

Negara yang bersangkutan dengan segera mengumumkan letak episenter dari gempa tersebut. Beberapa bulan kemudian solusi CMT yang memuat keterangan mengenai saat, lokasi dan mekanisme gempa (dalam bentuk tensor, [1]) tersebut diumumkan oleh Lembaga Seismologi Internasional.

Dalam penelitian ini, seismogram riil dari gempa Australia Barat, 10 Agustus 1997, dan gempa Australia Selatan, 25 Desember 2000, dibandingkan dengan seismogram sintetik [6]. Seismogram sintetik dihitung dengan metoda fungsi Green, dikenal sebagai GEMINI, atas model bumi elastik dengan solusi CMT dari gempa yang bersangkutan pada beberapa stasiun pengamatan. Stasiun pengamat, yaitu pencatat seismogram diambil di daerah sekitar sumber gempa, yaitu WRAB, NWAO, CTAO dan TAU. Alasan dipilihnya lokasilokasi sumber gempa dan stasiun-stasiun pengamat adalah, bahwa struktur tektonik pada model bumi antara episenter dan stasiun-stasiun observasi adalah sederhana. Ini ditunjukkan dengan sedikitnya gempa-gempa intra-plate yang terjadi di dalam daerah tersebut [3].

Dua model bumi yang terkenal, yaitu The Preliminary Reference Earth Model 81 (PREM), selanjutnya disebut PREMAN, dan IASPEI91 dapat dilihat pada Gambar 1.

Solusi tensor dari Gempa Australia Barat, 10 Agustus 1997, dan Gempa Australia Selatan, 25 Desember 2000, yang diumumkan dalam halaman WWW di ftp.iris.washington.edu/pub/CMT (penanggung jawab adalah Prof. Ekstro"m, Uni. Harvard) adalah sebagai berikut :

$\begin{array}{lllllllll}\text { C081097A } & 08 & 10 & 97 & 09 & 20 & 31.0 & -16.01 & 124.33\end{array}$ 10.05.96.0WESTERN AUSTRALIA

PDE $541214549931357.0 .1-15.98 .01124 .48 .0115 .0 .0$

$3.025 .33 .021 .39 .01-1.72 .02-1.21 .06-.91 .061 .38 .01$

$2.7931156-.46570-2.33112532 .56299601520177149$ dan

$\begin{array}{lllllllll}\mathrm{B} 122500 \mathrm{C} & 12 & 25 & 00 & 13 & 24 & 22.9 & -42.52 & 120.18\end{array}$ 10.05.85.6SOUTH OF AUSTRALIA PDE $55102450004.5 .2-42.35 .02120 .33 .0315 .0 .0$

$1.7244 .07 .06-2.66 .08-1.42 .08 .82 .32-1.18 .28 .86 .08$ $4.377864-1.057301-3.32102103 .8529235791265598$

Keterangan dari masing-masing nilai dapat dilihat pada file (allorder.dek.ex-plained) di halaman FTP di atas.

\section{METODOLOGI PENELITIAN}

Data seismogram dapat diperoleh dari beberapa Databank Center, yang datanya dapat diakses melalui halaman WWW, misal iris.washington.edu. Setiap gempa menghasilkan pergerakan tanah, yang oleh stasiun observasi akan direkam dalam arah ketiga komponen Kartesian (U-S, T-B dan Z). Setelah data diperoleh, kemudian difilter Butterworth lolos rendah pada $30 \mathrm{mHz}$, dan diputar pada bidang datar dan diperagakan untuk perbandingan seismogram dalam domain waktu.

Pertama dalam penelitian ini harus dituliskan program komputer untuk melaksanakan perhitungan berdasar metoda GEMINI [7, 8] untuk menghasilkan seismogram sintetik. Ketika program ini dijalankan, haruslah sebuah model bumi diberikan inputnya, yaitu model bumi PREMAN dan IASPEI91. Sebagai model bumi input, data harus mengandung parameter elastik secara lengkap, yaitu meliputi rapat massa, kecepatan jalar gelombang kompresi dan shear, faktor kualitas redaman, parameter anisotropi dari batuan penyusun struktur bumi.

Program GEMINI (Green's function of the Earth by MINor Integration) adalah menghitung minor dari fungsi-fungsi Green's atas suatu model bumi dan dengan suatu kedalaman sumber gempa tertentu. di mana fungsi-fungsi Green's diekspansikan dalam frekuensi komplex, dengan memasukkan trick damping untuk menghindari time aliasing. Program DISPEC (termasuk paket GEMINI) membaca posisi stasiun-stasiun penerima dan parameter-parameter moment tensor, yang tertera dalam solusi CMT baris ketiga. Posisi geographi episenter dan stasiun penerima ditranformasikan ke dalam koordinat pusat episenter (jarak episentral dan azimut) dan dihitung harmonik spherical untuk semua stasiun penerima. Program DISPEC membaca solusi basis Green's dari GEMINI, dan membentuk sumasi atas harmonik spferis dan mengadakan transformasi balik ke koordinat geografis, menghasilkan seismogram sintetik dalam kawasan frekuensi komplex. Program MONPR, mentranform seismogram sintetik frekuensi komplex ke time domain dimana sebelumnya dikenakan filter lolos rendah Butterworth dan RESPONSE file dari sistim peralatan seismometer di stasiun penerima, sehingga seismogram sintetik dan seismogram riil dibandingkan dalam dimensi yang sama. Untuk mengidentifikasi fe gelombang dalam seimogram digunakan waktu tempuh fse tersebut yang dihitung dengan program TTIME [9]. 


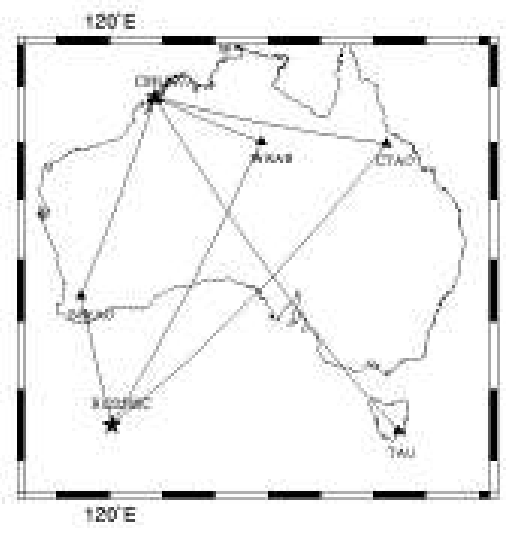

Gambar 2: Lintasan Gelombang antara episenter gempa C081097A \& B122500C dengan stasiun-stasiun observasi

Data runtun waktu seismogram terekam dalam arah tiga komponen, yang diarahkan pada arah Utara-Selatan, TimurBarat dan vertikal lokal di posisi stasiun observasi. Guna memperjelas perbandingan seismogram yaitu hipotesa atas teori penjalaran gelombang sferoidal (P-SV) dan gelombang toroidal (SH), maka komponen Kartesian dalam bidang datar diputar menurut sudut antara lokal Utara lokal dengan jalan gelombang ditarik dari stasiun observasi ke episenter (backazimuth), seperti dalam Gambar 2.

Gambar 3 dan berikutnya menunjukkan perbandingan seismogram riil dan kedua sintetiknya, masing-masing dari PREMAN dan IASPEI91. Masing-masing seismogram sintetik tersusun atas tiga trace, tiga di bawah PREMAN dan tiga di atas IASPEI91. Masing-masing trace dari bawah adalah komponen arah $\mathrm{z}, \mathrm{r}$ dan $\mathrm{t}$ (vertikal, radial dan toroidal).

\section{HASIL PENELITIAN DAN PEMBAHASAN}

Dalam penelitian ditampilkan analisa gempa Australia Barat 10 Agustus 1997 dan gempa Australia Selatan 25 Desember 2000, yang gelombangnya ditangkap oleh stasiunstasiun observasi seismologi WRAB, NWAO, CTAO dan TAU, semuanya terletak di Australia.

Stasiun observasi WRAB terletak dekat dengan pusat gempa, Gambar 3 menunjukkan bahwa amplitudo seismogram sintetik dari kedua model bumi terlalu besar dibanding amplitudo seismogram riil. Ini menunjukkan bahwa besar energi yang dilepaskan, seperti dideskripsikan dalam baris ketiga solusi CMT, lebih besar daripada yang seharusnya.

Gambar 4a menunjukkan perbandingan seismogram untuk segmen gelombang $\mathrm{P}$ di stasiun observasi NWAO. Terlihat minimum pertama gelombang $\mathrm{P}$ sintetik datang 3 detik lebih awal daripada $\mathrm{P}$ riil, begitu juga dengan fase-fase gelombang derivat gelombang P. Model bumi IASPEI91 memiliki ketebalan kulit bumi pada $35 \mathrm{~km}$, dan PREMAN $25 \mathrm{~km}$, terlihat seismogram sintetik dari IASPEI91 memiliki amplitudo yang lebih besar daripada sintetik dari PREMAN. Gambar $4 \mathrm{~b}$ memberikan ilustrasi untuk gelombang permukaan Love

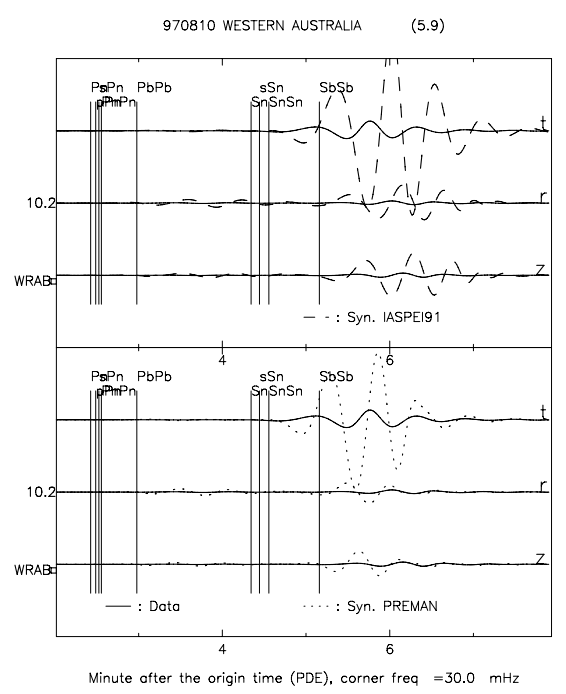

Gambar 3: Perbandingan seismogram untuk gempa C081097A di stasiun WRAB

dan Rayleigh, gelombang S tenggelam dalam gelombang permukaan. Terlihat pada gelombang permukaan, amplitudo seismogram sintetik tampak setinggi amplitudo gelombang permukaan riil. Namun gelombang Love sintetik, baik dari PREMAN ataupun IASPEI91, datang lebih lambat daripada Love riil, bahkan sampai 27 detik. Hal yang menarik untuk diamati di sini adalah bahwa model bumi IASPEI memberikan gelombang Love yang amplitudonya membesar ke belakang, sementara Love dari PREMAN besar amplitudo mengembang rata. Diskrepansi juga teramati pada gelombang Rayleigh, tetapi amlitudonya lemah dibandingkan gelombang Love.

Gambar 5a menunjukkan perbandingan seismogram gempa C081097A di stasiun CTAO pada jendela waktu gelombang P dan repetisi-nya. Terlihat kedua sintetik memberikan gelombang P sintetik yang datang lebih awal daripada gelombang $\mathrm{P}$ riil. Yang mengherankan, model bumi IASPEI memberikan $\mathrm{P}$ sintetik dengan amplitudo yang lebih besar, namun pada gelombang $\mathrm{P}$ repetisi di menit 7 ' memfitting dengan baik gelombang riil (Bagus, 2004). Gambar 5b menunjukkan, bahwa S sintetik dari PREMAN memberikan fitting yang baik, tetapi pada gelombang Love datang lebih awal, dan amplitudonya meluruh lebih cepat daripada gelombang Love riil. Pada gelombang Rayleigh, model bumi IASPEI91 memberikan amplitudo yang lebih setara daripada sintetik Rayleigh dari PREMAN, meskipun Rayleigh sintetik juga datang 6 detik lebih awal daripada gelombang Rayleigh riil. Perbandingan seismogram untuk gelombang ScS ditunjukkan dalam Gambar 5c. Terlihat, ScS sintetik datang 15 detik lebih awal dan dengan amplitudo yang lebih lemah daripada gelombang $\mathrm{ScS}$ riil.

Perbandingan seismogram gempa C081097A pada gelombang P di stasiun observasi TAU, dapat dilihat pada Gambar 6a. Terlihat, gelombang P sintetik datang 6 detik lebih lambat daripada $P$ riil. Ini berkebalikan dengan pengamatan pada gelombang P pada stasiun pengamat CTAO (Gambar 5a). Hal 


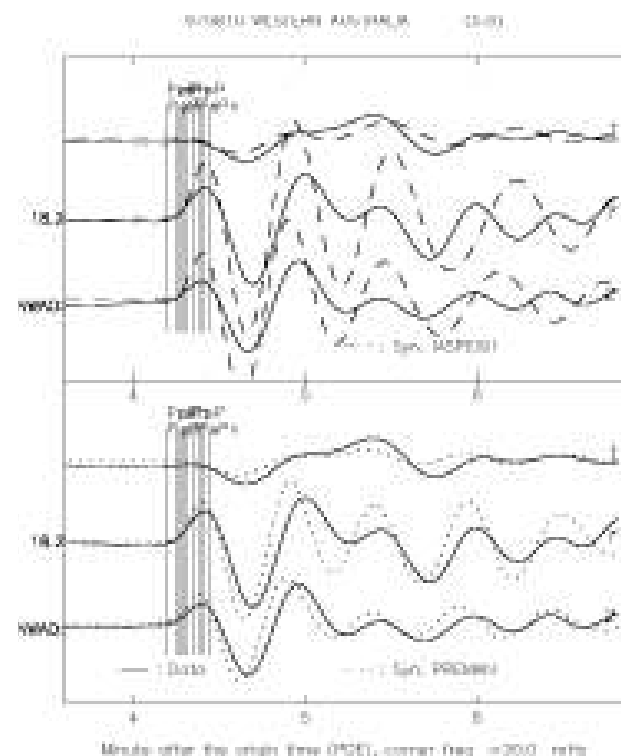

(a)P Wave

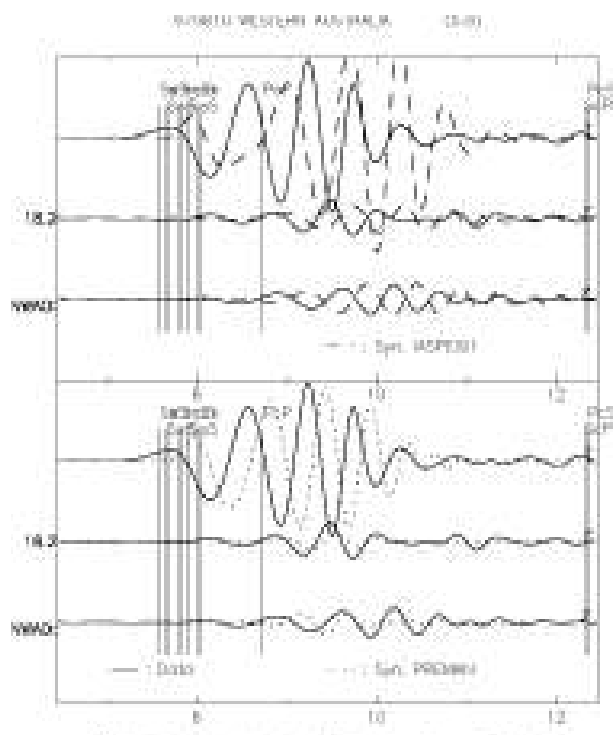

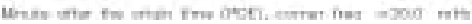

(b)S, L \& R Wave

Gambar 4: Perbandingan seismogram untuk gempa C081097A di stasiun NWAO,jendela waktu gelombang (a). P (b). S, Love dan Rayleigh

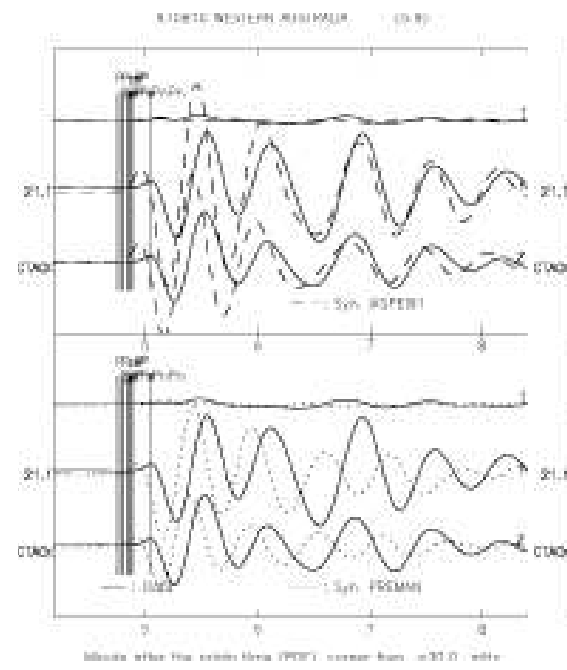

(a)P Wave

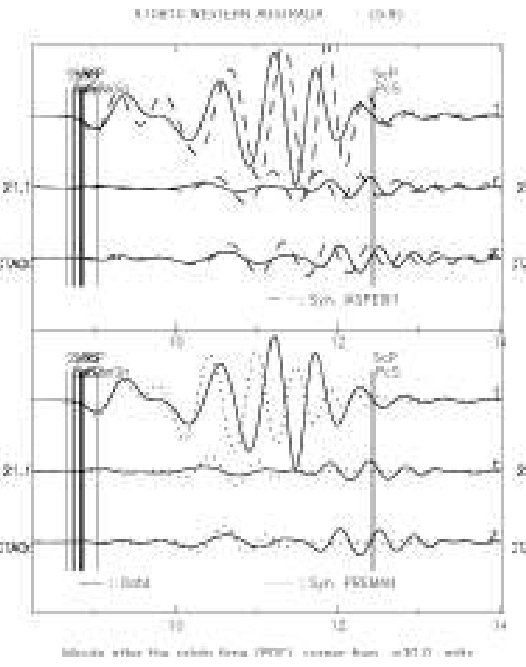

(b)S, L \& R Wave

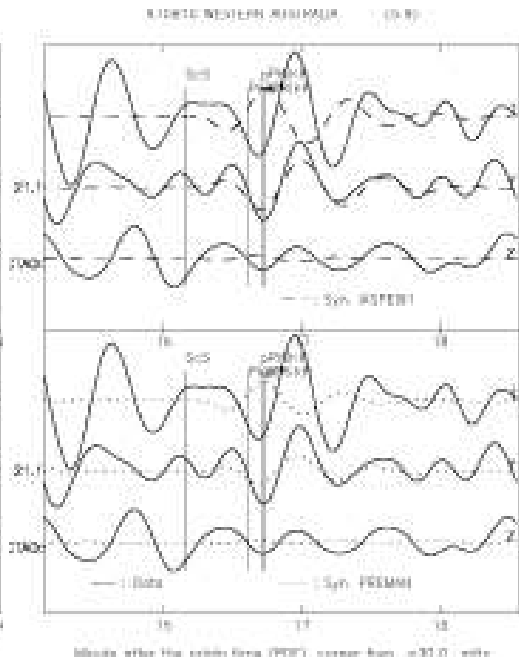

(c)ScS Wave

Gambar 5: Perbandingan seismogram untuk gempa C081097A di stasiun CTAO, jendela waktu gelombang (a). P (b). S, Love dan Rayleigh (c). $\mathrm{ScS}$

yang sama juga dapat diamati pada fase gelombang PnPn. Fenomena ketergantungan tinggi amplitudo pada ketebalan kulit bumi juga terlihat di seismogram ini. Gambar $6 \mathrm{~b}$ menunjukkan perbandingan seismogram untuk segmen gelombang S dan gelombang permukaan Love dan Rayleigh. Terlihat $\mathrm{S}$ sintetik dari kedua model bumi datang lebih lambat daripada S riil. Pada osilasi awal, gelombang Love riil datang lebih awal daripada osilasi Love sintetik, tetapi pada osilasi tengah hingga osilasi akhir gelombang Love riil dapat disimulasi dengan sangat baik oleh kedua model bumi. Pengamatan pada gelombang Rayleigh, menunjukkan Rayleigh sin- tetik dari IASPEI91 berlangsung hampir selama gelombang Rayleigh riil dan juga dengan tinggi amplitudo yang setara, sementara Rayleigh sintetik dari PREMAN meluruh dengan sangat cepat.

Setelah kita amati perbandingan seismogram dari gempa bumi C081097A pada gambar 3-6, berikutnya disajikan seismogram dari gempa B122500C dengan stasiun-stasiun observasi di WRAB, NWAO dan CTAO.

Gambar 7a menunjukkan perbandingan seismogram riil gempa $\mathrm{C} 122500 \mathrm{C}$ dengan sintetik-sintetiknya di stasiun observasi WRAB. Terlihat, gelombang P sintetik datang lebih 


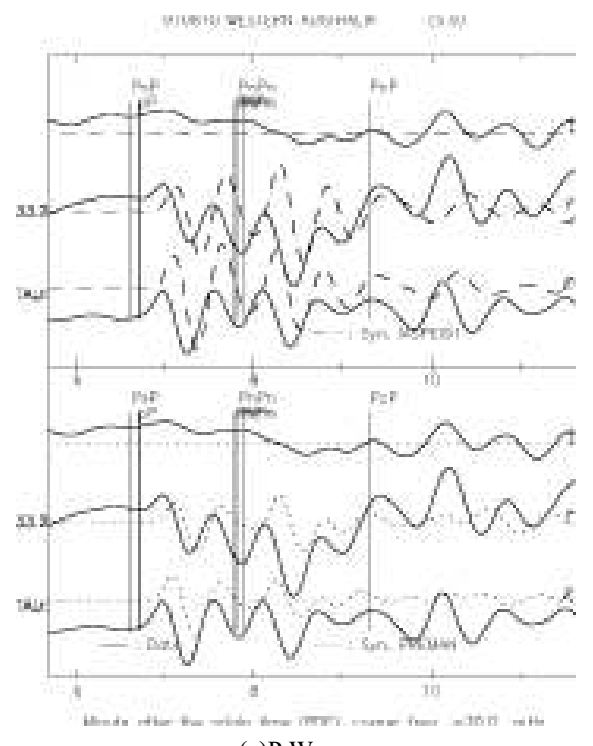

(a)P Wave

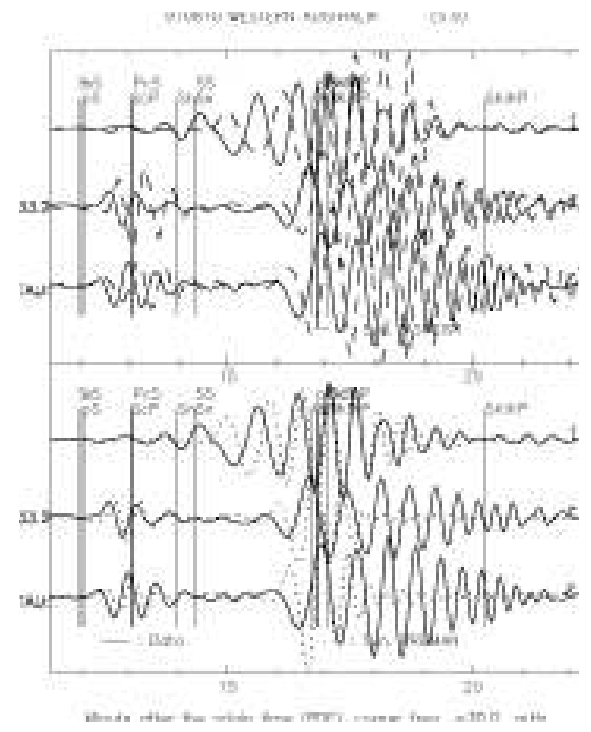

(b)S, L \& R Wave

Gambar 6: Perbandingan seismogram untuk gempa C081097A di stasiun TAU,jendela waktu gelombang (a). P (b). S, Love dan Rayleigh

lambat 9 detik daripada gelombang $\mathrm{P}$ riil. Fase gelombang dengan amplitudo yang jelas di waktu 7'40', juga disimulasikan dengan baik oleh kedua sintetik. Namun program TTIMES tidak memberikan notasi untuk fase gelombang tersebut, meskipun ragam fase gelombang yang dipilih adalah all. Perbandingan seismogram untuk fase gelombang S dilustrasikan dalam Gambar 7b. Terlihat gelombang $\mathrm{S}$ sintetik datang lebih lambat, dengan beda fase antara $\mathrm{S}$ riil dan sintetiknya di atas 1800 . Amplitudo gelombang S sintetik dari IASPEI91 lebih besar daripada yang dari PREMAN, ini adalah pengaruh dari beda ketebalan kulit bumi dari kedua model. Pengamatan pada gelombang Rayleigh menun-

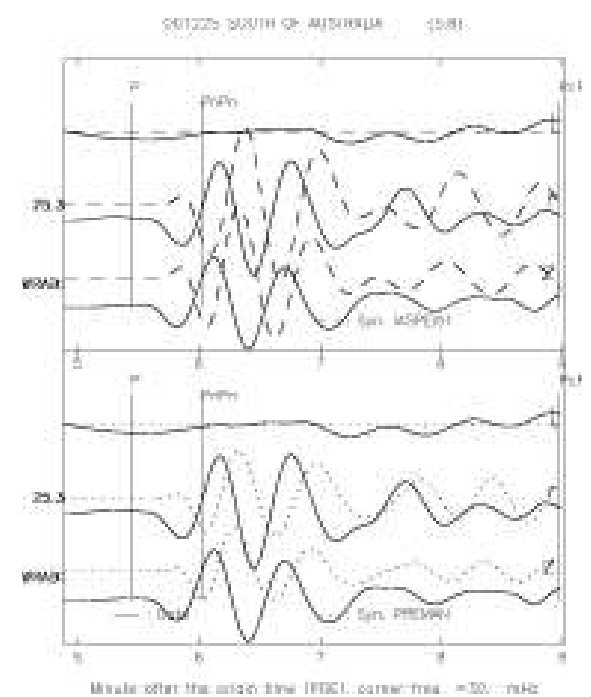

(a)P Wave

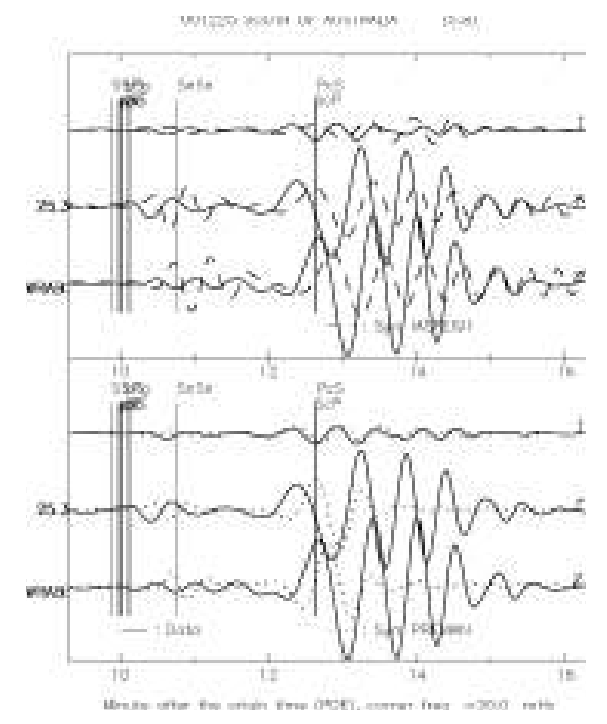

(b)S, L \& R Wave

Gambar 7: Perbandingan seismogram untuk gempa B122500C di stasiun WRAB, jendela waktu gelombang (a). P (b). S, Love dan Rayleigh

jukkan diskrepansi yang nyata pada kedua sintetik, gelombang Rayleigh riil lebih kuat, datang lebih awal dan berlangsung lebih lama daripada kedua sintetik.

Gambar 8 menunjukkan analisa seismogram gempa B122500C pada semua fase gelombang di NWAO, karena jarak episentral yang dekat, sehingga jendela waktu dari gelombang $\mathrm{P}$ hingga gelombang permukaan cukup pendek. Terlihat pada fase $\mathrm{P}$, gelombang $\mathrm{P}$ sintetik datang 5 detik lebih lambat, sementara gelombang Love sintetik berlangsung lebih lama daripada gelombang Love riil. Pengamatan pada gelombang Rayleigh menunjukkan pengamatan yang berlawanan, bahwa gelombang Rayleigh riil memiliki amplitudo yang lebih tinggi daripada kedua sintetik, dan gelombang 


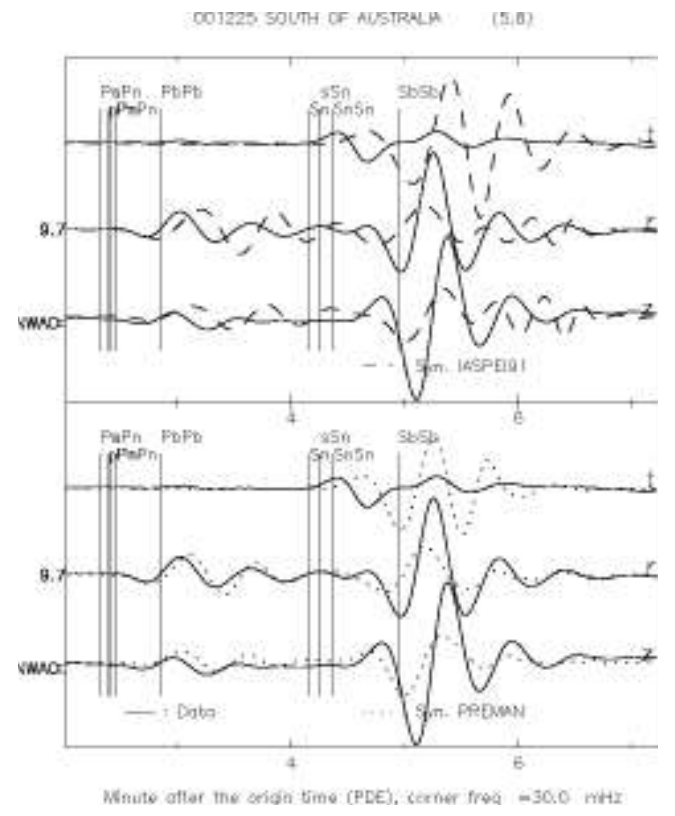

Gambar 8: Perbandingan seismogram untuk gempa B122500C di stasiun NWAO

Rayleigh sintetik datang lebih awal.

Gambar 9a memberikan ilustrasi mengenai perbandingan seismogram jendela waktu gelombang P di stasiun CTAO. Terlihat, bagaimana pengaruh ketebalan kulit bumi pada tinggi gelombang P. Walaupun waktu tiba gelombang P dan PnPn disimulasikan dengan baik, tetapi amplitudo gelombang kompresi riil yang kuat di 9'7', ditandai dengan fase PcP, gelombang sintetik dari IASPEI91 datang lebih lambat, sementara model PREMAN memberikan gelombang sintetik dengan waktu tiba yang baik tetapi dengan amplitudo yang lemah. Gambar 9b memperlihatkan perbandingan seismogram pada jendela waktu gelombang $\mathrm{S}$ dan gelombang permukaan Love dan Rayleigh. Gelombang S sintetik datang sedikit lebih awal daripada $\mathrm{S}$ riil, dan S sintetik dari IASPEI mempunyai amplitudo yang besar dan berlangsung lebih lama. Pengamatan pada gelombang Love, sintetik dari kedua model bumi mempunyai amplitudo yang lebih kuat daripada gelombang Love riil. Sedangkan pada gelombang Rayleigh, gelombang riil memiliki amplitudo yang lebih kuat daripada kedua sinetiknya. Disamping itu, mode dasar Rayleigh sintetik datang lebih awal daripada mode dasar gelombang Rayleigh riil.

\section{SIMPULAN}

Dari serangkaian perbandingan seismogram yang disajikan dari gambar 3-9 dapat kita simpulkan, bahwa solusi CMT yang dipublikasikan oleh Berkeley Seismological Laboratory melalui metoda TDMT-INVC [1] mengandung banyak kekurangan. Metoda GEMINI adalah metoda yang ekivalen dengan metoda sumasi mode [7], tetapi dapat menghitung seis-

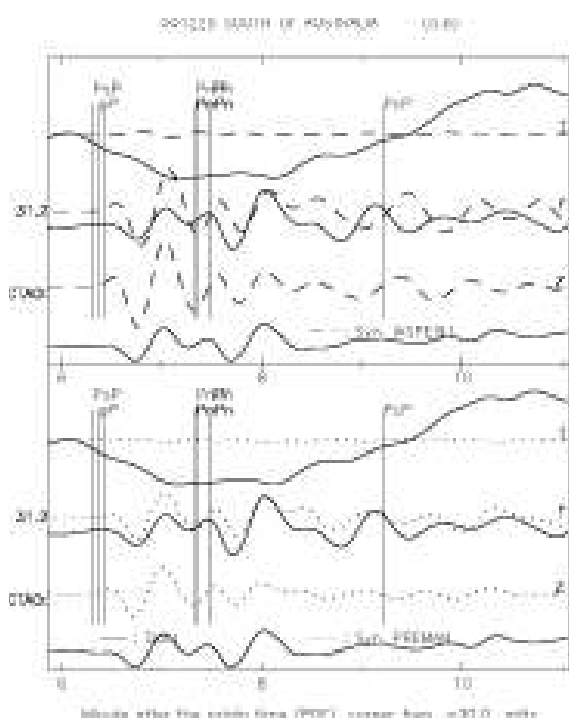

(a)P Wave

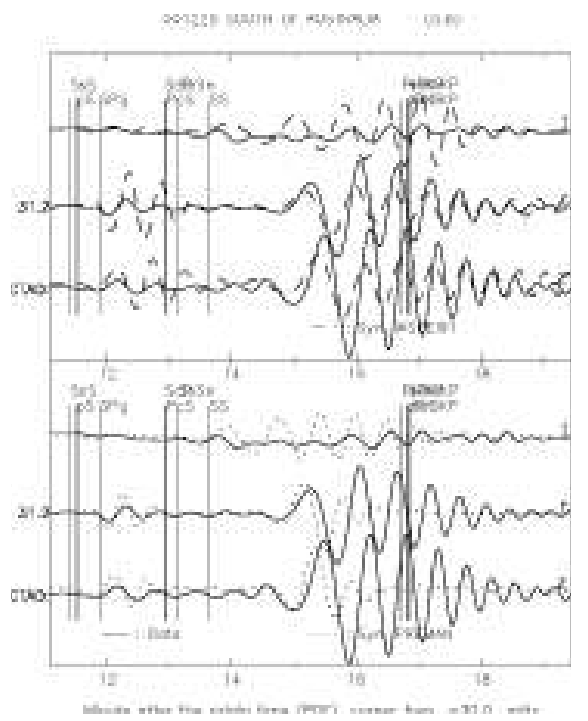

(b)S, L \& R Wave

Gambar 9: Perbandingan seismogram untuk gempa B122500C di stasiun CTAO, jendela waktu gelombang (a). P (b). S, Love dan Rayleigh

mogram sintetik dengan frekuensi hingga puluhan kali. Kedua model bumi, PREMAN dan IASPEI91 dan solusi CMT tidak memberikan seismogram sintetik yang menggambarkan kembali waveform-waveform fase utama dalam seismogram riil, baik fase ataupun tinggi amplitudo dan lama keberlangsungan gelombang permukaan. Disamping itu, gelombang Love ternyata sangat peka terhadap perubahan ketebalan kulit bumi, walaupun frekuensi corner adalah $30 \mathrm{mHz}$ atau panjang gelombang sekitar $120 \mathrm{~km}$. Pengaruh ketebalan kulit bumi juga dapat diamati pada amplitudo gelombang body $\mathrm{P}$ dan $\mathrm{S}$ sintetik, bahwa makin tebal kulit bumi, makin tinggi dan makin lama gelombang S sintetik dihasilkan. 
[1] Dreger, D.S., Time-Domain Moment Tensor INVerse Code (TDMT-INVC), The Berkeley Seismological Laboratory (BSL), report number 8511 (2002)

[2] Dziewonski, A.M., Chou, T.A. and Woodhouse, Jour. of Geophys. Res., 86, 2825-2852 (1981).

[3] Gubbins, D., Seismology and Plate Tectonics (Cambridge University Press, Cambridge, 1990)

[4] Kennett, B.L.N., Seismological Tables, Research School of Earths Sciences, Australian National University, IASPEI 1991.

[5] Dziewonski, A.M. and Anderson, D.L., Phys. of the Earth and Plan. Int., 25, 297-356 (1981).

[6] Bagus J.S, 2001, Mempelajari Model Bumi Berlapis dengan Seismogram, Majalah IPTEK, Vol 13, No 3, 25-33 (2001).
[7] Dalkolmo, J., Synthetische Seismogramme fuer eine sphaerisch symmetrische, nichtrotierende Erde durch direkte Berechnung der Greenschen Funktion, Diplomarbeit, Inst. fuer Geophys., Uni. Stuttgart,1993.

[8] Bagus J.S., Moeglichkeiten und Grenzen der Modellierung vollstaendiger langperiodischer Seismogramme, Doktorarbeit, Berichte Nr. 12, Inst. fuer Geophysik, Uni. Stuttgart,1999.

[9] Bulland, R. and Chapman, C., Travel time Calculation, BSSA, 73,1271-1302 (1983).

[10] Bagus J.S., Pengaruh ketebalan kulit bumi pada tinggi amplitudo gelombang P, Majalah IPTEK, Vol 15, No. 3, 1-5(2004). 